\title{
THE RELATIONSHIP BETWEEN CONDITION AND FORM FACTORS OF THE ADRIATIC FISHES IN THE ZADAR AREA
}

\author{
Tomislav Treer, Helena Babačić \\ University of Zagreb, Faculty of Agriculture, Department of Fisheries, Beekeeping, Game Management and \\ Special Zoology, Svetošimunska 25, 10000 Zagreb, Croatia
}

*Corresponding Author, Email: treer@agr.hr

\section{ARTICLE INFO \\ Received: 3 February 2017 \\ Received in revised form: 11 October 2017 \\ Accepted: 25 October 2017 \\ Available online: 6 November 2017}

\section{Keywords: \\ Fulton \\ Fish shape \\ Marine fish \\ Croatia}

\begin{abstract}
The relationship between the mean Fulton's condition and form factors of 12 marine species ( $\mathrm{N}=209$ fish specimens) caught in the Zadar area (middle eastern Adriatic) was analysed. The lowest mean condition factor ( $\mathrm{K}=0.6329)$ referred to the elongated Trachinus draco, while the highest one $(K=1.7758)$ referred to the deep-bodied Scorpaena porcus. The correlation between the mean Fulton's condition and form factors of these 12 populations was highly significant $\left(K=0.404+0.663 \mathrm{a}_{3.0} ; \mathrm{r}^{2}=0.815 ; \mathrm{P}\right.$ $<0.01$ ). Including more species in the calculation would give even more accurate results.
\end{abstract}

\section{How to Cite}

Treer, T., Babačić, H. (2017): The relationship between condition and form factors of the Adriatic fishes in the Zadar area. Croatian Journal of Fisheries, 75, 153-155. DOI: 10.1515/cjf-2017-0019

\section{INTRODUCTION}

Variations of Fulton's condition factor $(\mathrm{K})$ among the species stand within certain limits and depend upon a variety of biological (genetics, stages of development) and external (e.g. food availability, water quality, etc.) parameters. Variations of $\mathrm{K}$ between species are also influenced by the body shape (Treer et al., 2009; Hossain et al., 2012) which is well described by the form factor (Froese, 2006). Apart from such correlations among many species, the form factor can also be used to compare the same species in different water bodies (Hossain et al., 2013b). For sustainable fishery management and conservation, the form factor of just one fish population is also useful (Rahman et al., 2012). The aim of this paper was to determine the relationship between $\mathrm{K}$ and the form factor $\left(\mathrm{a}_{3.0}\right)$ for 12 Adriatic species in the Zadar area.

\section{MATERIALS AND METHODS}

The fish were caught by angling between April and May 2016 by the members of „Zubatac“ Zadar Sport Club during the competition and by one diver using speargun. Altogether 209 fish specimens belonging to 12 species were analysed. The mean $K\left(K=W \cdot L^{-3} \cdot 100\right)$ with respective $95 \%$ confidence limits $(C L)$ was calculated for each species with at least four specimens. The regression between these means and the respective form factors $\left(\mathrm{a}_{3.0}\right)$ was calculated according to Froese (2006):

$a_{3: 0}=10^{\log a-5(b-3)}$;

where $a$ and $b$ are mean coefficients of LWRs from FishBase (Froese and Pauly, 2016) and S (-1.358) is the mean slope of log a vs. b for all fish species (Froese, 2006).

Scientific names for each species were checked with the FishBase (Froese and Pauly, 2016). 


\section{RESULTS AND DISCUSSION}

The values of mean condition factors, with their respective 95\% confidence limits and form factors available for each species, are presented in Table 1. The lowest mean condition factor among 12 species with at least 4 specimens ( $K=0.6329)$ refers to the elongated Trachinus draco and the highest one $(K=1.7758)$ to the deep-bodied Scorpaena porcus.

Although condition factors can vary considerably over different seasons and ages, the geometric means for each species are relatively stable. These means of $\mathrm{K}$ depend mostly on the form of the fish, as shown in Fig. 1. The correlation between condition and form factors of these 12 populations (Fig. 1, solid circles) is highly significant ( $\mathrm{K}=$ $\left.0.404+0.663 a_{3.0} ; r^{2}=0.815 ; P<0.01\right)$. As $K$ for each species vary between certain limits, even the inclusion of $\mathrm{K}$ for only one specimen can fit into the regression. This is especially true for the specimens of the species with extreme body shapes, like Belone belone. The only caught specimen of this species $(\mathrm{L}=43.0 \mathrm{~cm})$ had $\mathrm{K}=0.18866$ and $\mathrm{a}_{3.0} \times 100$
$=0.1036$ (Fig. 1), what is even a smaller form factor than the one of the similarly shaped garfish Xenentodon cancila (Hossain et al., 2013a).

Although the aim of this paper was not to comment in detail $K$ for particular species, nor is this possible from these data, the mean values of $\mathrm{K}$ from other authors appeared to be close to these and fit into their confidence limits, e.g. 0.654 for Trachinus draco (Buz and Basusta, 2015), 0.843 (Yücel and Erkoyuncu, 2000) and 0.064-0.091 (Šantić et al., 2011) for Trachurus trachurus, 1.028 (Kara and Bayhan, 2015) and 1.025-1.029 (Dobroslavic et al., 2017) for Boops boops and 1.737 for Scorpaena porcus (Koca, 2002).

Similarly, most of the form factors multiplied by 100 fall within the confidence limits of $\mathrm{K}$ or very close to them (Table 1). Including more species in the calculation using the original data that satisfies recommendations by Froese (2006) (at least five LWRs with $r^{2}$ higher than 0.800 , outliers excluded, form factors correlated to Ks obtained from at least five populations) would give even more accurate results. Nevertheless, even these results indicate the importance of how body form of certain fish species influences the range

Table 1. Values of geometric mean of condition factor (K) with $95 \%$ confidence limits (CL), minimum (min) and maximum $(\max )$ and form factor $\left(a_{3.0} \times 100\right)$ for 12 Adriatic fish species

\begin{tabular}{|c|c|c|c|c|c|}
\hline Species & Mean K & $95 \% \mathrm{CL}$ & Min-max & $\begin{array}{l}\text { No. of specimens and } \\
\text { their length intervals } \\
(\mathrm{cm})\end{array}$ & $a_{3.0} \times 100$ \\
\hline Trachinus draco & 0.6329 & $0.5742-0.6915$ & $0.33-1.19$ & $\begin{array}{c}36 \\
13.5-28.5\end{array}$ & 0.6277 \\
\hline Trachurus trachurus & 0.9000 & $0.8189-0.9811$ & $0.58-1.13$ & $\begin{array}{c}13 \\
22.0-25.6\end{array}$ & 0.8206 \\
\hline Boops boops & 0.9501 & $0.8675-1.0327$ & $0.16-1.22$ & $\begin{array}{c}24 \\
20.0-24.6\end{array}$ & 0.8532 \\
\hline Coris julis & 1.1392 & $0.8759-1.4025$ & $0.97-1.31$ & $\begin{array}{c}4 \\
20.0-22.5\end{array}$ & 0.9591 \\
\hline Spicara maena & 1.1260 & $1.0342-1.2179$ & $0.74-2.19$ & $\begin{array}{c}50 \\
11.5-23.0\end{array}$ & 1.0700 \\
\hline Symphodus tinca & 1.4662 & $1.3336-1.5989$ & $0.55-2.73$ & $\begin{array}{c}39 \\
8.0-18.0\end{array}$ & 1.0910 \\
\hline Serranus scriba & 1.2240 & $0.9451-1.5029$ & $0.54-2.19$ & $\begin{array}{c}12 \\
9.0-19.5\end{array}$ & 1.3796 \\
\hline Pagellus erythrinus & 1.2641 & $1.1050-1.4232$ & $0.97-1.51$ & $\begin{array}{c}7 \\
17.1-21.5\end{array}$ & 1.5107 \\
\hline Serranus hepatus & 1.6760 & $1.5618-1.7901$ & $1.60-1.95$ & $\begin{array}{c}7 \\
8.5-10.0\end{array}$ & 1.6409 \\
\hline Diplodus vulgaris & 1.4890 & $1.1569-1.8211$ & $0.71-1.78$ & $\begin{array}{c}7 \\
17.5-27.0\end{array}$ & 1.7538 \\
\hline Diplodus annularis & 1.5723 & $1.3647-1.7798$ & $1.35-1.88$ & $\begin{array}{c}6 \\
12.0-15.5\end{array}$ & 1.8807 \\
\hline Scorpaena porcus & 1.7758 & $0.9676-2.5840$ & $1.02-2.08$ & $\begin{array}{c}4 \\
16.0-22.1\end{array}$ & 2.0599 \\
\hline
\end{tabular}


of its $\mathrm{K}$ values. If comparing the condition of various species, this fact in particular should be taken into account.

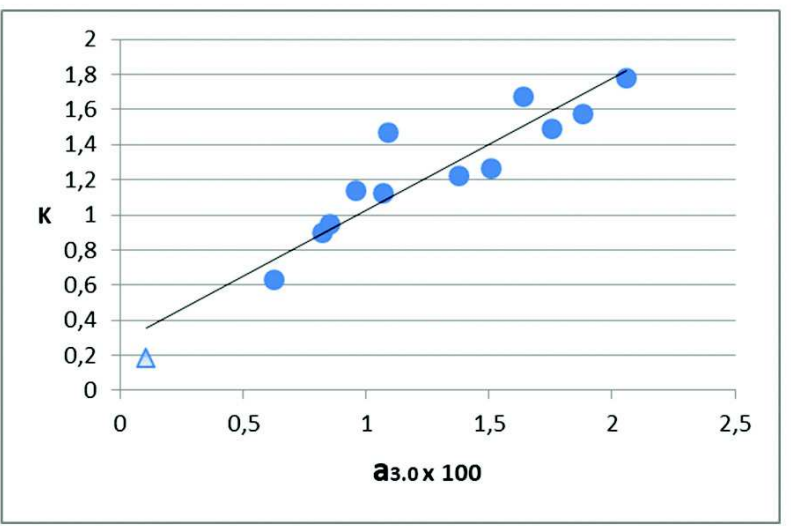

Fig 1. Plot of condition factor $(\mathrm{K})$ vs. form factor $\left(\mathrm{a}_{3.0}\right)$ for 12 Adriatic fish species $\left(\mathrm{K}=0.404+0.663 \mathrm{a}_{3.0} ; \mathrm{r}^{2}=0.815\right.$; $\mathrm{p}<0.01$ ) with at least 4 specimens (dots). The added Belone belone specimen is presented by the triangle

\section{Sažetak}

\section{ODNOS IZMEĐU FAKORA KONDICIJE I FAKTORA OBLIKA ZA RIBE ZADARSKOG PODRUČJA JADRANSKOG MORA}

Analiziran je odnos između srednje vrijednosti faktora kondicije i faktora oblika za 209 jedinki riba, odnosno 12 vrsta ulovljenih u travnju i svibnju 2016. god. na zadarskom području - središnji dio istočnog Jadranskog mora. Najmanji prosječni faktor kondicije zabilježen je kod izduženog pauka bijelca Trachinus draco (K=0,6329), a najveći kod zaobljenog škarpuna Scorpaena porcus $(K=1,7758)$. Korelacija između faktora kondicije i faktora oblika za ovih 12 vrsta je statistički značajna ( $\left.K=0,404+0,663 a_{3.0} ; r^{2}=0,815 ; P<0,01\right)$. Analizom većeg broja vrsta $\mathrm{i}$ jedinki ovi bi rezultati bili još precizniji.

\section{REFERENCES}

Buz, K., Basusta, N. (2015): Age and growth of the greater weever, Trachinus draco (Linnaeus, 1758) inhabiting Iskenderun Bay, North-eastern Mediterranean Sea. Cahiers de Biologie Marine, 56, 289-295

Dobroslavic, T., Mozara, R., Glamuzina, B., Bartulovic, V. (2017): Reproductive patterns of bogue, Boops boops
(Sparidae), in the southeastern Adriatic Sea. Acta Adriatica, 58, 117-124

Froese, R. (2006): Cube law, condition factor and weightlength relationships: history, meta-analysis and recommendations. J. Appl. Ichthyol., 22, 241-253

Froese, R., Pauly, D. (Eds), 2008: FishBase 2008. Available at: http://www.fishbase.org (accessed on January, 2017) Hossain, M. Y., Rahman, M. M., Jewel, M. A. S., Ahmed, Z. F., Ahamed, F., Fulanda, B., Abdallah, E. M., Ohtomi, J. (2012): Conditions- and Form-Factor of the Five Threatened Fishes from the Jamuna (Brahmaputra River Distributary) River, Northern Bangladesh. Sains Malaysiana, 41, 671-678

Hossain, M. Y., Jewel, M. A. S., Rahman, M. M., Haque, A. B. M. M., Elbaghdady, H. A. M., Ohtomi, J. (2013a): Life-history Traits of the Freshwater Garfish Xenentodon cancila (Hamilton 1822) (Belonidae) in the Ganges River, Northwestern Bangladesh. Sains Malaysiana, 42, 1207-1218

Hossain, M. Y., Rahman, M. M., Abdallah, E. M., Ohtomi, J. (2013b): Biometric Relationships of the Pool Barb Puntius sophore (Hamilton 1822) (Cyprinidae) from Three Major Rivers of Bangladesh. Sains Malaysiana, 42, 1571-1580

Kara, A., Bayhan, B. (2015): Age and growth of Boops boops (Linnaeus, 1758) in Izmir Bay, Aegean Sea, Turkey. Journal of Applied Ichthyology, 31, 620-626

Koca, H. U. (2002): A study on the determination of some parameters of the scorpion fish (Scorpaena porcus Linne., 1758) caught by bottom nets in the area of Sinop in terms of fishery biology. Turkish Journal of Veterinary \& Animal Sciences, 26, 65-69

Rahman, M. M., Hossain, M. Y., Jewel, M. A. S., Rahman, M. M., Jasmine, S., Abdallah, E. M., Ohtomi, J. (2012): Population Structure, Length-weight and Length-length Relationships, and Condition- and Form-Factors of the Pool barb Puntius sophore (Hamilton, 1822) (Cyprinidae) from the Chalan Beel, North-Central Bangladesh. Sains Malaysiana, 41, 795-802

Šantič, M., Rađa, B., Paladin, A. (2011): Condition and length-weight relationship of the horse mackerel (Trachurus trachurus L.) and the mediterranean horse mackerel (Trachurus mediterraneus L.) from the eastern Adriatic sea. Arch. Biol. Sci., 63, 421-428

Treer, T., Piria, M., Šprem, N. (2009): The relationship between condition and form factors of freshwater fishes of Croatia. Journal of Applied Ichthyology, 25, 608-610

Yücel, S., Erkoyuncu, I. (2000): Population dynamics of horse mackerel (Trachurus trachurus L., 1758) stocks in the Mid Black Sea, Turkey. Tr. J. of Biol., 26, 543-552 (in Turkish) 